\title{
Inleiding. Bruggen slaan
}

Wie een brug legt; naar een ander; kan altijd heen; en terug.

Jana Beranová, Tsjechisch-Nederlandse dichteres en vertaalster

Dit gedicht van de dichteres Jana Beranová, die in Nederland woont maar als Tsjechische vertaalster de literatuur uit Midden-Europa mee toegankelijk maakt in het Nederlands, staat symbool voor cultuurbemiddeling en het bruggen slaan tussen verschillende talen, literaturen en culturen. Het vormde meteen ook het thema van het dertiende regionaal colloquium neerlandicum van vereniging voor neerlandistiek in Centraal-Europa, Comenius, dat in mei 2019 georganiseerd werd aan de Comenius Universiteit te Bratislava. In dit nummer van Neerlandica Wratislavensia zijn nog enkele artikelen gepubliceerd waar de deelnemers hun paper gepresenteerd hebben. Het colloquium was met 84 deelnemers uit 15 landen en maar liefst 35 verschillende centra voor neerlandistiek opnieuw een bijzonder succesvolle bijeenkomst, na het regionaal colloquium te Wrocław in 2017, waar contacten konden bloeien met als gastschrijver Frank Westerman.

De afdeling Nederlands te Bratislava kent aan onze faculteit een traditie van vertalen en tolken van de Nederlandse taal en cultuur. Vertalen is bij uitstek een discipline die verbindt en bruggen slaat tussen een bron- en een doelcultuur en dit colloquium heeft dan de aanwezigen uitgenodigd, uitgedaagd en gestimuleerd om bruggen te slaan tussen verschillende disciplines onderling.

Daarbij zijn we uitgegaan van het principe van Lateraal denken. In 1970 introduceerde Edward De Bono dit psychologisch principe om creativiteit te stimuleren via een methode van zes denkhoeden. Normaal gezien is een mens geneigd om een zo recht mogelijke lijn te volgen van begin tot einde via bekende wegen. Maar wat gebeurt er als we platgetreden paden verlaten en bruggen slaan naar andere disciplines, tussen culturen, talen, literaturen, vakken en beroepen met behulp van nieuwe denkmethodes, creativiteit, optimisme en pessimisme, emoties en intuïtie, probleemdenken en schijnbare onmogelijkheden terug reëel 
maken? De bijdragen in dit nummer van Neerlandica Wratislavensia zijn in elk geval een weerslag van de diversiteit, het bruggen bouwen en interculturele contacten in alle aspecten van de neerlandistiek zowel intra als extra muros.

De artikelen zijn thematisch en inhoudelijk gegroepeerd. Als eerste geeft Wilken Engelbrecht een unieke inkijk in de praktijken van het Tsjechoslowaakse staatsliterairagentschap DILIA en het plaatsen van vertalingen van Nederlandse en Vlaamse schrijvers in Tsjechoslowakije en beschrijft de reconstructie van het uitgeven van vertalingen in de periode van het socialistisch realisme met hulp van archiefmateriaal uit het literair museum in Den Haag. Ook Jakob Faber houdt zich bezig met vertalingen, maar dan specifiek van één auteur uit het Hongaars, namelijk Imre Kertész. Zijn bijdrage situeert zich als verbinding tussen Midden-Europa en het Nederlandse literaire veld. Hij gaat op zoek naar de receptie van de Hongaarse schrijver en Nobelprijswinnaar in een aanzet om zijn vroegste oeuvre in Nederlandse recensies in kaart te brengen.

De daaropvolgende artikelen situeren zich bij de oudere en vroegmoderne literatuur. Els Stronks legt in haar artikel over de dienende Datheen de stelling van Mike Kestemont, die Petrus Datheen met technieken uit de digital humanities aanwees als mogelijke auteur van het Wilhelmus nogmaals aan de methodologische toetssteen van de close reading. In een contrastief onderzoek naar de dienaar-knecht metafoor in zijn oeuvre versterkt ze de hypothese van Datheen als mogelijke auteur van het Wilhelmus.

Lotte Jensen, Hanneke van Asperen, Adriaan Duiveman, Marieke van Egeraat, Fons Meijer, Lilian Nijhuis situeren hun onderzoek in de traditie van de disaster studies en onderzoeken de omgang van de Nederlandse media bij rampen en de gemeenschapsvorming die daarbij hoort. Met hulp van vroegmoderne nieuwsmedia, gelegenheidsgedichten en enkele visuele bronnen poneren zij dat culturele media een erg belangrijk hulpmiddel waren om nu eens eenheid en gemeenschapsvorming, dan weer verdeeldheid te bevorderen.

Bij Stefan Kiedroń ligt een vergelijking van de zeventiende eeuwse dichters Vondel in Nederland en Jan Andrzej Morsztyn aan Poolse zijde aan de basis om hun politieke ideeën achter hun gedichten bloot te leggen, met een rijke beeldvorming over de Sarmatenmythe voor de Polen en de rijkdom van het koren en de Oostzeehandel die voor de Nederlanden heel belangrijk was. Opmerkelijk is het feit dat Morsztyn bijzondere relaties in Leiden en de Republiek der Zeven Verenigde Nederlanden aangeknoopt had.

Anna Krýsová brengt in haar bijdrage een literair-theoretische beschouwing van contemporaine literatuur. Met behulp van een corpus teksten die voor een deel "overlijdensberichten van het postmodernisme" zijn, wil ze de begrippen poetics of politics en "affectieve dominant" in kaart brengen als dominante concepten die gebruikt worden om contemporaine literatuur te beschrijven, in het bijzonder tegenover de contextualisering en periodisering van het postmodernisme. 
De volgende twee bijdragen zijn cultuurhistorisch qua thematiek en bieden opnieuw aanknopingspunten met zowel Polen als Hongarije en de Lage Landen. Gábor Pusztai beschrijft in zijn bijdrage voornamelijk de kinderacties na 1945 en speciaal door liefdadigheidsorganisaties ingelegde kindertreinen die ingezet werden om Hongaarse kinderen in Nederland en België te laten aansterken. Uit zijn getuigenissen blijkt dat de politiek hierbij een grote rol speelde.

Joanna Skubisz brengt ons in haar bijlage naar het Silezische Krzyżowice, waar in een paleis typische Nederlandse wit-blauwe tegels hangen. Zij geeft naast een historisch overzicht van het paleis zelf ook een analyse van de beelden die van Nederland gepresenteerd worden op de tegels als het idyllische Nederlandse platteland, dat aansluit bij het beeld van Nederland in literatuur en kunst.

De laatste artikelen vinden we in het vakgebied van de vertaalwetenschap en taalwetenschap. Michal Homola presenteert in zijn bijdrage enkele bevindingen van het vakgebied rond sociaal tolken of de meer international gangbare term public service interpreting in een historische schets, waarbij Vlaanderen als een schoolvoorbeeld van goede beroepspraktijk geldt voor dit soort tolken. Hij concentreert zich tot slot op enkele problematische aspecten van het public service tolken in Slowakije.

Katarzyna Wiercińska gaat in haar bijdrage op zoek naar de directheid en de beleving van dit woord onder Nederlandse en Poolse taalgebruikers. In een analyse naar de onderliggende waarden van direchtheid, namelijk duidelijkheid, onbeleefdheid, eerlijkheid, sociale hiërarchie en afstand wil ze aan de hand van haar onderzoeksresultaten mogelijke misverstanden in de communicatie tussen Polen en Nederlanders te verklaren.

Tot slot biedt dit nummer van Neerlandica Wratislavensia nog twee recensies aan. Judyta Kuznik bespreekt de publicatie De Hongaarse kindertreinen. Een levende brug tussen Hongarije, Nederland en België na de Eerste Wereldoorlog van Maarten Aalders, Gábor Pusztai en Orsolya Réthelyi, en Damian Olszewski de herwerkte versie van het Nederlandstalige Het leven van teksten van Kiene Brillenburg Wurth en Ann Rigney als The Life of Texts. An Introduction to Literary Studies.

We wensen alle recensenten van dit nummer te danken voor de waardevolle opmerkingen en tot slot de Nederlandse Taalunie, die het mogelijk maakte om de publicatie van dit colloquiumnummer te financieren.

Benjamin Bossaert

ORCID: 0000-0002-9086-9812

Univerzita Komenského v Bratislave

Marketa Štefková

ORCID: 0000-0001-8641-2492

Univerzita Komenského v Bratislave 